\title{
IRISH-AMERICAN PATRIOTISM: THE TRANSATLANTIC POLITICS AND HUMANIST CULTURE OF COLUM MCCANN
}

\author{
ALFRED MARKEY \\ Universidad de León \\ alfred.markey@unileon.es
}

Received 29 July 2020

Accepted 11 October 2020

KEYWORDS Irish-American; patriotism; humanism; transatlantic; Colum McCann; identity; public intellectual; Frederick Douglass; The Gathering; Washington Consensus.

PALABRAS CLAVE Irlandés-americano; patriotismo; humanismo; transatlántico; Colum McCann; identidad; intelectual público; Frederick Douglass; The Gathering; Consenso de Washington.

\section{ABSTRACT}

This article proposes the novel TransAtlantic, from the IrishAmerican writer Colum McCann, as an example of what Edward Said called a "countermemory." Such a countermemory facilitates the taking of critical positions against what the British intellectual Tony Judt called the "Washington Consensus:" the ideological 'pensée unique' which has dominated the Western world in recent decades, resulting in the substitution of an ethically-informed public conversation by a powerful discourse which prioritises, above all, the values of the so-called marketplace. This article explores how, via his historical novel, his participation as a public intellectual and through his concept of identity as art, McCann gives us a world of different values, values of trans-national and universal solidarity which implicate figures from Frederick Douglass to Barack Obama or the Hollywood actor Gabriel Byrne, and are expressed perhaps most radically in the language of what we may call an IrishAmerican "patriotism."

\section{RESUMEN}

Este artículo propone la novela TransAtlantic del escritor irlandésamericano Colum McCann como ejemplo de lo que Edward Said ha llamado una "contramemoria." Dicha contramemoria sirve de toma de posición crítica ante lo que el intelectual británico Tony Judt denominó el "Consenso de Washington:" el 'pensée unique' ideológico que ha dominado el mundo occidental en las últimas décadas, y ha 
supuesto la sustitución de una conversación pública de carácter ético por un poderoso discurso que prima, por encima de todo, los valores del mercado. El artículo explora cómo, a través de su novela histórica, de su participación como intelectual público y de su concepto de identidad como arte, McCann presenta un mundo de valores distintos, valores de solidaridad trans-nacional y universal que implican a figuras desde Frederick Douglass hasta Barack Obama o el actor de Hollywood Gabriel Byrne, expresándose quizá más radicalmente a través del lenguaje de lo que podemos llamar un "patriotismo" irlandés-americano.

Speaking before a hugely enthusiastic crowd at College Green, Dublin on May 23 2011, American President Barack Obama warmly recalled his visit earlier in the day to Moneygall, the small town in the Irish midlands from which his great-great-great grandfather, Falmouth Kearney, had departed for America in the late 1840s, and reflected:

$[\mathrm{H}] \mathrm{e}$ left during the Great Hunger, as so many Irish did, to seek a new life in the New World. He traveled by ship to New York, where he entered himself into the records as a laborer. He married an American girl from Ohio. They settled in the Midwest. They started a family. It's a familiar story because it's one lived and cherished by Americans of all backgrounds. It's integral to our national identity. It's who we are, a nation of immigrants from all around the world.

Kearney was, no doubt, heartbroken as he left behind the coast of Ireland but, Obama imagined, sustained by "faith in the idea of America," by what was, in effect, the American Dream. It was this same dream which had, the President noted, inspired his own father to travel from Kenya in the second half of the $20^{\text {th }}$ century and its inheritance was precisely something Obama himself fervently sought to "carry forward" in what he articulates as a continuing journey through "stormy waters."

The speech was very warmly received and although some critical comment suggested it was aimed more at the Irish-American electorate than the listening Irish, the resonant imagery and suggestive message were considered inspiring by most. Coming a few days after the hugely symbolic visit of Britain's Queen Elizabeth, the President's remarks were seen to offer a similar potential for a creative reimagining of political identity away from stale models 
which had served to bolster entrenched notions of identitarian thought, such as those clearly implicated in the history of conflict in Northern Ireland. Among those who appear to have been inspired figures the Irish-American author Colum McCann.

McCann's 2013 novel TransAtlantic has at its heart the story of a young Irish woman, Lily Duggan, who during the Irish Famine crossed the ocean before establishing a family in the American Midwest. Tracing the fortunes of this family to the present day, the novel concludes with the last surviving member of a line of female descendants of Duggan, the now elderly Hannah Carson who, on the occasion of the Obama/Queen visits, forms an impromptu family group with the Kenyan academic David Manyaki and his Irish wife and children. Given this apparent hommage, in this article I wish to address McCann's novel while relating it to some of the traditions of political thought invoked by Obama and how they, in turn, relate to existing and potential paradigms of ethnic and political identity which implicate both America and Ireland. A parallel transatlantic critical dialogue will also be established between a significant America-based project of cultural performance promoted by the actor Gabriel Byrne and defended by McCann, and an alternative Irish government initiative to engage the diaspora which is reflective of a much less enabling model of cultural and political identity.

This latter initiative, known as The Gathering, was in its own words "a nation-wide celebration of who we are and what we stand for," involving the promotion throughout 2013 of activities in Ireland encouraging the return of members of the diaspora, particularly from America ("Homeward"). The project presented itself as a grass-roots, popular movement which attempted to engage creatively with the Irish diaspora. It was not, however, universally celebrated by the diaspora itself. Most significantly, the former Irish cultural ambassador in the USA Gabriel Byrne criticized it as a shake-down, a bare-faced attempt by home-based politicians to fleece tourists in an effort to kick-start the Irish economy in deep difficulty since 2008. Speaking on Irish radio, Byrne lamented that:

The only time the diaspora, or Irish Americans are ever mentioned, is as tourists and how can we get these people here to boost our tourism and how can we get people back here so that we can shake them down for a few quid.' ("Actor") 
Clearly, for Byrne, The Gathering's idea of clarifying who the Irish are and what they stand for is shaped excessively by the perception of the diaspora as tourists, as consumers of Irishness rather than as participants in the debate: as creators and signifiers of a multifaceted, complex identity which maps its space of signification not just within the borders of the Irish state but in its traffic with the world and, especially, in its cross-Atlantic dimension. Byrne's frustration is easy to comprehend. What awaited the travelling Americans was mostly a proliferation of carrot-throwing competitions, wellington boot races, all manner of get-togethers around what at best can be called folksy notions of Irish identity, and a defining discourse of the sort initially found on the official webpage's "What it Means to be Irish" section:

Being Irish is claiming not to watch the Eurovision but secretly knowing every one of our winning entries. It means quoting Father Ted; calling crisps Taytos; knowing 'no' means 'yes' to a cup of tea and among other characteristics a tendency towards hospitality and well, that, and our really big welcome mat. (We're not messing, it's massive).

One could protest that this was but harmless fun. It does, however, aim towards the very serious issue of self-definition, something which involves choices: the prioritisation of one vision, one sort of discourse over another, and here it is imperative that we connect the puerile chatter and stereotyped self-representation characteristic of much of the Gathering phenomenon with broader ideological frameworks. In broad sympathy with Byrne's protestations, one can propose that a clear link can be made between this unchallenging commodification of Irishness, the attempt to recruit as "customers" those Americans whose notion of ethnic identity involves an element of Irishness, a culture of consumerism consistent with globalization and a consequently diminished role for alternative meanings or identity narratives which do not give clear priority to the values of the marketplace.

The Gathering was the product of an emergency situation. In the wake of the 2008 crisis which brought the so-called Celtic Tiger Irish economy crashing to a sudden halt, with a bailout of the banks and the dramatic deflation of a housing bubble, initiatives were 
proposed which could kick-start the Irish economy. ${ }^{1}$ Significant among these was the "think-tank" which produced the idea of The Gathering, the Global Irish Economic Forum held in Dublin in 2009 and brainchild of the celebrity economist David McWilliams. It thus comes as no surprise to find that the discourse which justifies both of these initiatives is overwhelmingly marked by the language of the world of business, commerce and economics.

The urgency of the economic situation not only accentuates the use of an idiom already dominant but is also manifest in an impatience with what are seen as less pragmatic and less productive modes of thought and expression. For example, at the launches of the Forum and The Gathering political leaders very specifically sought to restrict the parameters within which the discussion of ideas took place. In his keynote speech to the Forum the then prime minister, Brian Cowen, stated: "I hope our discussions will lead to a number of practical outcomes to help with the current economic challenge," before going on to be brutally clear about the purpose of engaging with the diaspora: "[t]ime and again, that resource has paid dividends in Ireland's past." His successor, Enda Kenny, declared at its opening that "The Gathering is serious business, with serious commitment and serious gains to be made," while the Minister of State for Tourism, Michael Ring, said "We're looking for your help and support on this. We want positivity, no negativity. We want everyone working on this. We have a great country, great community, great people" (qtd. in Holland).

Evidently, neither the Global Irish Economic Forum nor The Gathering prioritised the encouragement of broad-ranging or indepth discussion of ideas or a re-examination of the language and intellectual inheritance that shaped Ireland's conception of what it was. While Barack Obama could speak of "who we are" in the language of national identity articulated by means of narratives involving origins, journeys, families, and dreams, Brian Cowen's hard-core language, by contrast, proposed that "Ireland is a small, open economy which has to earn its living by selling to world markets. The Ireland we envisage for the future is a smart, highvalue, export-led economy." Unquestionably, this discursive tendency

\footnotetext{
${ }^{1}$ For a general overview of the impact of the 2008 financial crisis in both Europe and the USA see Lewis, particularly the chapter "Ireland's Original Sin." For key studies on the Celtic Tiger see Kirby et al.; Ó Riain (2000); Kirby (2004) and O'Hearn. On the aftermath of the crisis in Ireland see Kirby (2010); O’Toole; and Ó Riain (2014).
} 
has been particularly marked in the Irish context but it is essential that we relate it to a broader phenomenon, to more gradual trends the genesis of which takes us back across the Atlantic to its American source.

British historian and public intellectual Tony Judt has offered some valuable insights on the broader context. In his 2010 essay $\mathrm{Ill}$ Fares the Land Judt condemned the ideological model dominant in the West for the previous 30 years, especially the obsession with material self-interest which has largely hijacked what he calls "collective purpose" (1). Notions of justice or rights, or enquiry over how to achieve a better society have lost protagonism to a world view in which "we know what things cost but have no idea what they are worth" (1). Judt writes:

The materialistic and selfish quality of contemporary life is not inherent in the human condition. Much of what appears 'natural' today dates from the 1980s: the obsession with wealth creation, the cult of privatization and the private sector, the growing disparities of rich and poor. And above all, the rhetoric which accompanies these: uncritical admiration for unfettered markets, disdain for the public sector, the delusion of endless growth. (2)

The rhetoric of which Judt speaks is clearly apparent in the language of politicians such as Cowen and Kenny, or their successor Leo Varadkar, but also in the authoritarian quality of pronouncements such as that from Minister Ring. In its attempt to forestall any questions, Ring's language is totalising in nature, it does not invite conversation except that which is uncritically affirmative of the dominant ideology and which, in turn, lends authority to a jingoistic triumphalism characteristic of reactionary politics. Judt indicates that the crisis since 2008 should have served as a warning that change was needed but that far from taking a different course "we seem unable to conceive of alternatives," and this is precisely because of the decline in a culture of critical engagement and debate (2).

Judt places the blame at the feet of the Washington Consensus and the army of economists and "experts" who loudly proclaimed the values of neoliberalism and globalization (6). ${ }^{2}$ Such

2 The term "Washington Consensus" was coined in a 1989 paper "What Washington Means by Policy Reform" from John Williamson of the Washington based think-tank Peterson Institute for International Economics (PIIE). Williamson has protested that 
discourse had its source in the values of the American Right but, crucially, its broader dominance was the result of its authorization by intellectuals who championed its values not just within the US but beyond, especially in Europe:

The Washington doctrine was everywhere greeted by ideological cheerleaders: from the profiteers of the 'Irish miracle' (the propertybubble boom of the 'Celtic Tiger') to the doctrinaire ultracapitalists of former Communist Europe. Even 'old Europeans' were swept up in the wake. The EU's free-market project - the so-called 'Lisbon agenda;' the enthusiastic privatization plans of the French and German governments: all bore witness to what its French critics described as the new 'pensée unique.' (6-7)

Ill Fares the Land was written, the author indicates, in order to "challenge conventional wisdom on both sides of the Atlantic" and to promote a renewed debate around ideas such as liberalism and social democracy (4-6). Quiescence at the dominant political and ideological model needs to be countered by a public conversation which is ethically informed and dissents against "our economically driven way of thinking" (9).

Broadly, while the discourse of Ring and The Gathering target a public seen to be passive consumers, Judt's position is that the urgency was not the economic crisis but the need to engage with people in such a way as to move them, to encourage their participation in debate as citizens actively interpreting the broad heritage of human ideas with deep historical resonances, and not just remain within the confines of the dominant 'pensée unique.' Such conversation invites critical reflection on a history of ideas in constant reinterpretation and movement, particularly back and forth across the Atlantic.

Similarly, when the American President travelled to Ireland and invoked the idea of the American dream he was, in effect, critiquing the Washington Consensus with its fetishization of the contemporary marketplace and its promotion of a singular narrative

the use of the term has been inconsistent with his original intentions, but it has become a shorthand for market fundamentalism, or neoliberalism, and been particularly associated with the legacy of the economic policies of the political administrations of Ronald Reagan in the U.S.A. and Margaret Thatcher in the UK. Williamson provides an overview of the debates around the use of the term in "A Short History of the Washington Consensus." See also Naim; Stiglitz and Schoenfelder; Marangos; and Munck. 
of success. Obama de-territorializes or dislocates the American dream away from its heartland of triumphalist expression, and, instead of exporting a static prototype of success, his identity narrative proposes ancestral touchstones as remote and disparate as Kenya and Ireland, and consciously evokes the history of the traffic of ideas and people central to an emancipatory tradition of which he is both a symbol and a conscious reinterpreting agent. He moves his audience from complacency. His American dream is one of universal reach in which the broad family of humanity must by right find a place.

This was not, however, universally acclaimed. Throughout his political career Obama suffered from attacks on his authenticity as an American, with reactionary elements in the media questioning his family narrative to the extent that his birth in America was placed in doubt. We can recognise the openly populist journalists who delegitimised and censured Obama as belonging to the camp of ideological cheerleaders identified by Judt, and see, in their sustained targeting of what America's first Afro-American president represented, evidence of a cultural war of authoritarian tenor, with real fallout for the idea of participative democracy. ${ }^{3}$ Edward Said has suggested that "we are bombarded by prepackaged and reified representations of the world that usurp consciousness and preempt democratic critique" and it is, for Said, imperative that what he calls the humanist and public intellectual should contest the growing influence of the neoliberal media, critique the dominant idiom and re-trope it in more enabling directions (Humanism 71). He writes:

For if, as I believe, there is now taking place in our society an assault on thought itself, to say nothing of democracy, equality and the environment, by the dehumanizing forces of globalization, neoliberal values, economic greed (euphemistically called the free market), as well as imperialist ambition, the humanist must offer

\footnotetext{
${ }^{3}$ Obama's successor, Donald Trump, was an early protagonist of attempts to question Obama's authenticity as an American, the so-called "birther" movement. He was primarily facilitated by the Fox News television channel, largely owned by the Murdoch family whose media empire has been a consistent advocate for the values of the Washington Consensus. For journalistic perspectives on the above see Siddiqui's "Fox News: How an Anti-Obama Fringe Set the Stage for Trump" and Mahler and Rutenberg's "How Rupert Murdoch's Empire of Influence Remade the World." For a sociological perspective on the influence of Rupert Murdoch see Arsenault and Castells' "Switching Power: Rupert Murdoch and the Global Business of Media Politics: A Sociological Analysis."
} 
alternatives now silenced or unavailable through the channels of communication controlled by a tiny number of news organizations. (Humanism 71)

Significantly, Said argued that the silencing of alternatives had been notably accentuated after the 9/11 attacks on New York. What was perceived as an emergency situation had as its consequence an intensified suspicion of people, ideas and identity narratives which did not manifestly coincide with those of the American heartland. The subsequent demonization of Obama in some sectors can be seen as evidence of the consolidation of this insular turn -the accentuation of a distinction between self and other-, while his eventual success in achieving office as the first Afro-American president can, by contrast, be interpreted as the response of an alternative tradition whose ideological positions and inspirations are reflective of an American intellectual legacy as authentic as that current which loudly and triumphantly proclaims its constricting story of national identity.

If we return to The Gathering and to Gabriel Byrne's questioning of the values which underpinned it, we can see in the intemperate reaction where the actor's measured views were vilified in the Irish press, a phenomenon similar to that identified by Said and reflective of the dominant 'pensée unique.' In essence, Byrne was condemned as unpatriotic, as a victim of his status as a Hollywood star which left him no longer in touch with the authentic sentiments of his homeland and consequently now more American than Irish. So much so that the aforementioned Minister Ring remarked "I didn't like his comments. I felt it was unpatriotic. I felt that he could have put the green jersey on this one," (Kelly). While Byrne's reaction led to many column inches and air-time, the absence of support for the actor from prominent figures of the cultural world was notable, with the clear exception of his fellow "American," Colum McCann.

Writing in The Irish Times on the eve of the symbolically significant national holiday, St. Patrick's Day, McCann, in terms suggestive of Said's critique of contemporary media culture, lamented that Byrne had been "hung out on a soundbite," that "his words were amplified into a tabloid weather report" ("Irish"). While Byrne was proposing a reimagining of Irish identity and a renewed paradigm of belonging, this was reduced to a parody and he to a part as the villain of the piece. Taking on a public intellectual role, McCann provides a broader, more nuanced narrative, a backstory 
which puts Byrne's words in context and so invites the reader to appraise the complexities of the actor's intervention and how his ideas relate to the struggles ongoing between alternative ideological models:

What Byrne has been suggesting for the best part of a decade is an intricate reimagining of what it means to be Irish. [...] No more of the lepracorny bullshit. No more dismantling of enlightened social legislation. No more vapid political smiles. No more stunned submission to greed. No more demolition of heritage. ("Irish")

In his interpretation of Byrne's intentions, McCann highlights a heritage of enlightened ideas which have produced social legislation, the crucial role culture plays in the ongoing renewal of this heritage, and the threat to this legacy from empty political rhetoric and public submission to the values of unfettered commercialism. In essence, the "lepracorny" version of Irish culture deploys a static, reified notion of national identity which serves the needs of commerce and tourism and relegates emancipatory ideas to a testimonial role. McCann recognises both the serious consequences of the acceptance of the current model, that which gains expression in the likes of The Gathering, and the potential of alternatives, particularly those which speak to and engage with Ireland's radical history and its articulation to a broader constituency beyond the space of the state itself, most significantly along that key historical cross-Atlantic axis crucial to the traffic of ideas that has shaped both the USA and Ireland.

McCann writes:

What Byrne has engaged in is a radical act of patriotism not seen in this country for many many years. Not only are the arts a vibrant part of our national life, he says, but they also give contour to the manner in which we cannot allow ourselves to become an ongoing Paddy's Day cliche. ${ }^{4}$ ("Irish")

\footnotetext{
4 Byrne's "radical act of patriotism" is most apparent in his leadership, as cultural ambassador, of the Imagine Ireland 2011 initiative, a year of Irish arts in America. Although funded by Culture Ireland, its webpage reveals a project radically different to The Gathering: "Imagine...Ireland. It's only an ocean away. And the ocean is nothing when you stand on the bedrock that has connected Ireland and the United States for well over a century. That bedrock is cultural; it is comprised of the way we think, the way we imagine, the way we create." During 2011 Imagine Ireland supported more
} 
The choices involved in McCann's intervention are significant. By choosing the symbolically resonant national day, he is announcing the ambition of what he and Byrne are attempting, and by underscoring the importance of cultural and artistic expression, he is placing these at the heart of his interpretation of the significance of Irishness, its relationship to history and its current and future state. Cliched language is that which is fossilized in the manner of the discourse of authenticity which demands an unchanging signification incompatible with continued expression. By contrast, to perform language in the unfolding present demands renewed significance consistent with creation. This is an active process of artistic intervention which allows for an engagement with the language and ideas of the past while doing so in a fashion contingent on articulation or performance which, so to speak, moves from the position of origin to engage with the audience or interlocutor, what is the other.

While the language of authenticity, whether that of the autarkic early decades of the Irish Free State or that of the commodified, globalized version of recent years, insists on fixity, on staying in place, the radical, performative model of McCann and Byrne is predicated on movement away from home. McCann reflected in his article in defence of Byrne: "[o]dd word, home. It seems to exist in only one place, but we cart it with us wherever we go" ("Irish"). Here we can identify an interpretative position similar to that of Obama in the Dublin speech. Obama's "home" implies accommodation of complex narratives of history and an articulation of a lived sense of this heritage with home understood as an ongoing journey, a liberating idea. Significantly, in his Irish Times article McCann has the word "home" written in bold type. He clearly wishes to draw attention to its centrality in the vision both he and Byrne have of identity.

Home is a concept expressed in the language of art. He writes: "Art is where we get to practise our identity. It's another chance at telling our story. [...] It is also our opportunity to align ourselves with the sort of people that many of us would like to be" ("Irish"). That alignment involves a repositioning of home in America. We have mentioned that TransAtlantic includes what appears to be an

than 500 cultural events across the US and also led to Byrne sharing the podium with Obama on his Dublin visit. 
hommage to Obama and his public "performance" of belonging to Ireland, and here, in a parallel act, McCann's defence of Byrne establishes as the cornerstone of his concept of home, its location and performance precisely in New York.

Although the article is entitled "Irish Identity is Work of Art Not Political Expediency," it opens with an evocative image of 11th Avenue in New York, where "the wind soughs in off the Hudson river" and locates here the borders which define what he attempts to articulate: "you can also feel the distinct pulse of the new -the cranes and scaffolding arcing across the dark. There is an element of 21 stcentury frontier about the shoeshine shops and tiny bodegas still hanging around the hem of the skyscrapers." Here at this frontier, "on the ground around 51st Street" is where, in considerable measure due to the efforts of Byrne, a new Irish Arts Centre was planned to come into existence by 2016, the centenary of the foundational moment of the 1916 uprising which devastated the urban centre of Dublin but gave rise to what became the Irish Republic. "An auspicious year," McCann calls it, while indicating the theatre will provide "[c]utting-edge spaces for intimate performances. Meeting rooms for artists and thinkers and businesspeople. A haven" ("Irish"). ${ }^{5}$

We get from McCann, then, a sense of a contemporary urban idyll, a spiritual home only possible in American exile from the Irish version of the Washington Consensus where the utopian discourse which precipitated the Irish Republic could be reinterpreted and reperformed in an enabling fashion. Whereas in the past the project for national liberation involved the imagination of the rural heartland as a national idyll, this legacy now finds appropriate expression in a deterritorialized Irish-American patriotism acted out at the heart of the American metropolis. 6

\footnotetext{
5 The timetable proved ambitious, with construction starting in October 2018 and a new completion date set for late 2020 .

${ }^{6}$ McCann's previous novel, Let the Great World Spin, was set in New York. It recreates the interconnected lives of a multitude of characters on 7 August 1974 when acrobat Philippe Petit walked across a wire between the top floors of the city's Twin Towers. Anne Fogarty has written that the novel "concretizes aspects of New York as a global and internally divided city and proleptically serves as an apt memorial to those killed on 9/11 [...]" (106). Awarded the American National Book Award, it states McCann's credentials to be considered an American as much as an Irish writer and offers evidence of his public intellectual role, his constant attempt to connect his fiction with worldly debates, with the public sphere, and, in this case the physical, public space. For critical work on McCann's fiction see particularly Flannery and Cahill's 2012
} 
This haven is here given artistic shape in motion, in the form of the Hudson river which "has carted across its affinity with the Lee, the Barrow, the Liffey," the Irish rivers with which it is here imaginatively twinned ("Irish"). The idea of motion, central to the trope of interconnected rivers, appropriately articulates the idea of theatrical performance and is suggestive of debate, conversation and the comprehension of alternating perspectives and currents, essentially the incorporation of the other into the act of selfexpression. McCann's choice of imagery is perhaps shaped in anticipation of the publication a few months later of TransAtlantic, where the idea of intercommunicating rivers gains expression in the defining motif of the novel, that of the ocean itself as a space of interaction and as a conduit of ideas and language.

The novel narrates a series of Atlantic crossings by sea and air, with a chronological span from the famine-era visit to Ireland of the black American anti-slavery campaigner Frederick Douglass up to the visit of Obama himself, while also tracing the genealogical trail of the family of the illiterate Dublin maid Lily Duggan who, inspired by the words of Douglass, crossed to the other, American side. The destiny of succeeding generations of Duggan's descendants provides the central narrative thread and the novel comes to a close when the last of a series of female protagonists, the elderly Hannah Carson, of Ulster unionist descent, crosses and re-crosses the Irish border to consult the Dublin-based Kenyan scholar, and Douglass expert, David Manyaki, on the worth of an unopened letter handed down to her. This was done in the hope of staving off eviction from her home by a bank under pressure following the collapse of Ireland's Celtic Tiger economy.

The letter turns out to have no market value as Douglass memorabilia. It does, however, awaken a spirit of solidarity in the Kenyan and his Irish wife for the welfare of the vulnerable Carson, bringing them together at the book's close. McCann affords the letter, the word, and language itself a central role in the communication of values whose worth cannot be calculated in narrow monetary terms. The letter is a legacy which connects and creates an affinity among this closing multicultural party, while also drawing the reader back through a family history in which ideas and ideals played a determining role, on both sides of the Atlantic, in allowing

collection of essays and Flannery's 2011 monograph. See also Cusatis; Gilligan; and Tucker. 
succeeding individuals achieve growing degrees of liberty, a value which in the contemporary moment is compromised by the restricted manual of behaviour used by professionals of the banking sector.

Written in 1919 by the pioneering American journalist Emily Ehrlich, the letter was given to the British airmen Alcock and Brown before the first transatlantic plane journey. Addressed to a family in Cork, Ireland, the letter was never delivered but handed down, unopened, to Carson. Ehrlich was, in fact, Carson's grandmother, and a daughter of Duggan, while the addressees of the letter were the possible descendants of Isabel Jennings and the content an expression of gratitude to this Miss Jennings on account of "a kindness" shown by her to Duggan (291). ${ }^{7}$ Reflecting on how the letter imaginatively connected people through history, Carson mused: "We return to the lives of those who have gone before us, a perplexing Möbius strip until we come home, eventually to ourselves" (248).

This eloquent testimony of TransAtlantic's last protagonist is best understood in relation to the portable notion of home articulated by McCann in defence of Byrne and the Obama Dublin speech which provides a shadowy palimpsest to the novel. There is thus an acknowledgement of an inheritance, a sense, as Akeel Bilgrami puts it in the foreword to Said's Humanism and Democratic Criticism, that "to know ourselves in history is to see ourselves as objects" but that also, in the exemplary manner of Said, inspired by the hermeneutical, humanist tradition dating back, in part, to Giambattista Vico, if we allow for "the fully cosmopolitan basis for self-criticism" we can combine self-knowledge of our cultural inheritance with resistance of it through opening up to engage with the traditions and ideas of other cultures (xii). The result is that "The 'Other,' therefore, is the source and resource for a better, more critical understanding of the "Self"' (xii). Such an approach means that "a concern for all that is human [can be] linked, not just contingently but necessarily, to this capacity for self-criticism" (xi).

Said places the critical capacity which is developed from humanistic, literary and philological enquiry, what in shorthand is called reading, at the centre of his poetics and this he directly links to democracy and the need for individuals to be active in the

\footnotetext{
7 Jennings was secretary of the Cork Ladies Anti-Slavery Society in the 1840s. During his visit to Cork Douglass stayed with the Jennings family, becoming close to Isabel with whom he subsequently corresponded.
} 
interpretation of the liberationist heritage which allows for citizenship and agency. McCann's letter similarly demands a critical reading which shifts its worth from the merely economic to values which involve a "coming home to ourselves," the recognition of a subjective core appropriate to liberated citizens who achieve agency and the ability to determine the direction the world may take, but also the understanding that this can only be achieved through the acknowledgement of universal humanity in its variety and plurality. This ontological paradigm is intersubjective and it depends on solidarity, precisely the idea which McCann places at the heart of his novel.

In Dublin Obama recalled:

When we strove to blot out the stain of slavery and advance the rights of man, we found common cause with your struggles against oppression. Frederick Douglass, an escaped slave and our great abolitionist, forged an unlikely friendship right here in Dublin with your great liberator, Daniel O'Connell. His time here, Frederick Douglass said, defined him not as a color but as a man. And it strengthened the non-violent campaign he would return home to wage.

McCann uses the Douglass visit as the chronological starting point of his novel. He thus chooses to affiliate with this evocative figure and the values he stands for, so actively retroping them for today. Obama highlighted how the mutual conceptualization by O'Connell and Douglass of each other not through a language of racial separation, but of common humanity, enabled the advance of the rights of man. In McCann's depiction of Douglass he identifies him as a man of letters and clarifies that he had crossed the Atlantic "to convince the people of Britain and Ireland to help crush slavery through peaceful moral persuasion" (38). The man of letters is a man of literature, of artistic creation, but his métier is participation in the public space, the transfer of his ideas to the people to allow them become critically-aware, participative, emancipated citizens. He is a public intellectual.

McCann renders the reaction of Douglass to first witnessing O'Connell as follows:

Douglass caught eyes with O'Connell. They nodded to each other. He watched the Irishman move away. [...] But to have that command, thought Douglass. That charm. That energy. To be able to 
possess the stage in such an extraordinary way. To stir justice without violence. The way the words seem to enter the very marrow of the people who still hung around the dockside [...].

Two days later, in Conciliation Hall, O'Connell brought him on stage and he thrust Douglass's hand in the air: Here, he said, the black O'Connell! Douglass watched the hats go up into the rafters. (59-60)

O'Connell, in his public performance of himself, appears to only achieve a plenitude when his identity as the Liberator involves his affiliation with Douglass. His own liberty, and that of his nation can only have a deep ethical sense and the power of a just cause when it implicates all of humanity and gives expression to an emancipatory paradigm of self-expression in peaceful interaction with the other. McCann gives us an intersubjective performance of identity in which the public rhetoric of solidarity expressed by O'Connell attempts to "enter the very marrow of the people" and become the very stuff of their conceptualization of selfhood (59). O'Connell cedes his place on the public stage to Douglass and allows the American to, in effect, speak with his voice, with his "energy" in a common articulation of freedom.

McCann writes of Douglass's invention thus:

-Irishmen and Irishwomen ...

[...] Thank you, he said, for the honour of allowing me to speak with you. He held out his hands and calmed the crowd and spoke to them of slavery and commerce and hypocrisy and the necessity of abolition.

An energy to him. A fire. He heard the ripple of his words move through the crowd.

-If you cast one glance upon a single man, he said, you shall cast a glance upon all humanity. A wrong done to one man is a wrong done to all. No power can imprison what is good and right. Abolition shall become the natural thought of the world! (60)

McCann creates a Douglass shaped from the mould of O'Connell. Identity, he has indicated, is a work of art and in this joint, theatrical performance of thoughts or ideas, expressed in the human bond between these two great men, and beyond them to the listening crowd and the whole world, ideas such as abolition or human justice and the rights of man are afforded greater purchase, so aiming towards the achievement of the condition of being natural. 
Douglass comes to voice by speaking "with" the Irish, but in a language which demands a fully public articulation of universal liberty beyond the particularity of his engagement with them. ${ }^{8}$ Liberty is contingent on its re-articulation as a lived social practice. Like the "idea of America," as Obama put it, it only makes sense when it actively disavows frontiers of exclusion and embraces those of all backgrounds. Similarly, by drawing a contrast between this performative language of solidarity and today's corporatist discourse, which repeats stale stereotypes while naturalising behaviour such as that of the bank which divests the elderly Carson of the rights to her home, McCann also reinterprets his own role and identity as artist by distinguishing between the values which have become natural in today's world and those which have historically enabled the liberation of Afroamericans, women and the native Irish.

In the final essay of Humanism and Democratic Criticism, "The Public Role of Writers and Intellectuals," Said proposes that "The intellectual is perhaps a kind of countermemory, with its own counterdiscourse that will not allow conscience to look away or fall asleep" (142). We can propose that McCann provides a timely countermemory and shows his readers that alternative worlds do and have existed and may continue to exert influence in today's world. ${ }^{9}$ The epigraph, that key paratextual touchstone to the novel here a quotation from the anti-globalization intellectual, Eduardo Galeano- emphasizes precisely this dimension: "No history is mute. No matter how much they own it, break it and lie about it, human history refuses to shut its mouth. Despite deafness and ignorance, the time that was continues to tick inside the time that is" (vii). Crucially, performative engagement with history implicates, and attempts to bring to bear in today's world, the complex resonance of

\footnotetext{
8 For Douglass's time in Ireland see Sweeney; Ferreira; and Riach. O'Connell's antislavery activism is examined in Murphy; and Kinealy. For an overview of Ireland's involvement in slavery see Rodgers. O'Connell's anti-slavery credentials have also been recently revisited in the light of the controversy over statues of historical figures linked to the slave trade. For such a defence of O'Connell see Collins.

9 McCann's public intellectual role is nowhere more explicit than as the co-founder and President of Narrative 4, which is, as its webpage indicates: "a global network of educators, students and artists that uses art and storytelling to build empathy between young people while equipping them to improve their communities and the world." Set up in 2013 it now has a presence in for continents and 12 countries and aims to equip "people to use their stories to build empathy, shatter stereotypes, break down barriers, and -ultimately- make the world a better place. If we share today, we'll change tomorrow."
} 
the history of ideas. It allows us grasp the poverty of an ideological 'pensée unique.'

In "Colum McCann's Latest High-Wire Act Links Home and America," a May 2013 interview on TransAtlantic, the novelist ends once again talking about patriotism, both of Byrne and the American Loretta Brennan Glucksman (Duggan). In essence, we are invited to read of, and interpret, a joint Irish-American patriotism, which, like the novel, demands the conception of a cross-Atlantic space and involves an oblique presentation of the national location, but also a further complicating engagement with the past. Negotiating the IrishAmerican axis of his identity, McCann suggests distance, in a sense living away from a conventional notion of home, allows him engage "intellectually and poetically" to a greater degree (Duggan). This is, one can propose, a highly significant balancing act indicative of a paradigm of engagement which allows McCann evoke and so, in effect, re-trope an historical patriotism as countermemory to contemporary loyalties.

In Said's essay on writers and intellectuals he contrasts the world of the great polemicist Jonathan Swift with that of the vast global dimensions at which the intellectual must today tilt, while also availing of Swift as exemplar of the writer-intellectual characterized by a "mobile intellectual energy" with the potential to give form to an "incipient community of intellectuals" (Humanism 132). That Swift should serve Said's needs is not surprising. In Humanism and Democratic Criticism he emphasises how the writer-intellectual has an enhanced ability to play a "special symbolic role," that "of the writer as intellectual testifying to a country's or region's experience, thereby giving that experience a public identity forever inscribed in the global discursive agenda" (127).

Scholars have attributed to Swift a symbolic role in bringing about a broad community of intellectual thought credited with giving impetus to patriotic sensibility in Ireland, and, as with McCann, a primary motivation for his intervention in the public sphere was the attempt to engage a broad constituency in protest against what was perceived as the predominance of economic values detrimental to society, those of a British empire specifically exploitative of Ireland. Padhraig Higgins indicates that in the late Eighteenth-Century period patriot sentiment, particularly in the 1778-79 boycott of British goods, gained expression in a "broad-based campaign organized around associations, mobilizing ordinary consumers around the country" (88). This is seen as an extension of the Swiftian 
move to go beyond the confines of the elite Anglo-Irish class to which he belonged, a turn considered of paramount importance in the development of a modern sense of Irish nationhood shaped to the template of enlightenment ideas such as universal rights, liberty and public prosperity. ${ }^{10}$ Crucially, however, in addition to the influence of the Swiftian tradition, Irish patriot sentiment became increasingly shaped by the American crisis, that rebellion which brought about American liberty:

The patriots could now fuse the potent combination of constitutional and commercial grievance, to which the American precedent gave the oxygen of publicity. Issues of sovereignty, imperial rights, mutual obligations were all aired incessantly in both countries, and an emerging sense of a shared grievance and a shared destiny developed. Benjamin Franklin argued that America's struggle was Ireland's struggle and he was rapturously received by the radicals on his Dublin visit in 1771 [...]. (Whelan 218)

As the Irish patriot politician Henry Flood put it: "A voice from America [had] shouted to liberty, the echo of it caught your people as it passed along the Atlantic, and they re-echoed the voice till it reverberated here" (Whelan 219).

In his utilization of a vocabulary of patriotism, Colum McCann in turn re-tropes or echoes the values that underlay these enlightenment ideas of liberty, rights and citizenship, so allowing an ethically-informed discourse of such historical reverberation to again travel back and forth across the Atlantic in order to dissent against the narrow, economically-shaped orthodoxies hegemonic in today's world. His is thus, as he said of Byrne's public work, "a radical act of patriotism" which is not anchored to the national space but is hybrid in its origins. It is Irish-American, its praxis always mobile, forever travelling and demanding re-performance.

In his rendering of it into living art, McCann reinvigorates and makes relevant for today a long tradition, a countermemory of IrishAmerican patriotism without which a full comprehension of the significance of either Ireland or America is impossible. His task and his achievement is appropriately reflected in the words of Obama on that May 2011 day in Dublin, words which may have given shape to McCann's idea for TransAtlantic, and which, echoing Bilgrami, allow

\footnotetext{
${ }^{10}$ For the development of patriot ideas in Ireland and the role of Swift, see Duddy.
} 
us recognize ourselves in history as objects while enabling a liberating agency which demands a mutual, intersubjective expression of identity infinitely more radical than that born from slavish consumerism or the cultivation of a sullen, insular nationalism:

That is the story of America and Ireland. That's the tale of our brawn and our blood, side by side, in making and remaking a nation, pulling it westward, pulling it skyward, moving it forward again and again and again. And that is our task again today.

\section{WORKS CITED}

"Actor Gabriel Byrne Labels The Gathering a 'Scam'." RTE, November 6, 2012. https://www.rte.ie/news/2012/1106/344428-the-gatheringgabriel-byrne/. Accessed June 25, 2020.

ARSENAULT, Amelia, and Manuel Castells. "Switching Power: Rupert Murdoch and the Global Business of Media Politics: A Sociological Analysis." International Sociology, vol. 23, no. 4, 2008, pp. 488-513.

BILGRAMI, Akeel. Foreword. Humanism and Democratic Criticism, by Said, Columbia UP, 2004, pp. ix-xiii.

CAHILL, Susan and Eóin Flannery. This Side of Brightness: Essays on the Fiction of Colum McCann. Peter Lang, 2012.

COLLINS, Stephen. "Why Ireland Should Be Proud of Daniel O'Connell and his Dublin Statue." The Irish Times, June 26, 2020.

COWEN, Brian. "Opening Speech." The Global Irish Economic Forum, September 18, 2009, http://www.globalirish.ie/tag/farmleigh/page/2/. Accessed June 23, 2013.

CUSATIS, John. Understanding Colum McCann. University of South Carolina Press, 2012.

DUDDY, Thomas. A History of Irish Thought. Routledge, 2002.

DUGGAN, Keith. "Colum McCann's Latest High-Wire Act Links Home and America." The Irish Times, May, 20, 2013. 
FERREIRA, Patricia J. "Frederick Douglass in Ireland: the Dublin Edition of His Narrative." New Hibernia Review, vol. 5, no. 1, 2001, pp. 53-67.

FLANNERY, Eóin. Colum McCann and the Aesthetics of Redemption. Irish Academic Press, 2011.

FOGARTY, Anne. “An Instance of Concurrency': Transnational Environments in Zoli and Let the Great World Spin." This Side of Brightness: Essays on the Fiction of Colum McCann, edited by Susan Cahill and Eóin Flannery, Irish Academic Press, 2012, pp. 103-28.

Imagine Ireland. http://imagineireland.ie/. Accessed June 26, 2020.

GILLIGAN, Ruth. "Towards a 'Narratology of Otherness': Colum McCann, Ireland, and a New Transcultural Approach." Studies in the Novel, vol. 48, no. 1, 2016, pp. 107-125.

HIGGINS, Padhraig. A Nation of Politicians: Gender, Patriotism and Political Culture in Late Eighteenth-Century Ireland. University of Wisconsin Press, 2010.

HOLLAND, Kitty. "Gathering to Promote Ireland All Next Year." The Irish Times, May 12, 2012.

"Homeward Bound." The Gathering, www.youtube.com/ playlist?list=PL44DvX1ZZ5Yj8nYYPGmmU185HG qvOQj24. Accessed June 25, 2020.

JUDT, Tony. Il Fares the Land. Penguin, 2010.

KELLY, Dara. “Actor Gabriel Byrne Called 'Unpatriotic' by Irish Government Minister." Irish Central, November 18, 2012, https://www.irishcentral.com/news/actor-gabriel-byrne-calledunpatriotic-by-irish-government-minister-179851511-237539411. Accessed May 25, 2020.

KINEALY, Christine. Daniel O'Connell and the Anti-slavery Movement: 'The Saddest People the Sun Sees.' Routledge, 2015.

KIRBY, Peadar. Celtic Tiger in Collapse: Explaining the Weaknesses of the Irish Model. Springer, 2010.

---. "Development Theory and the Celtic Tiger." The European Journal of Development Research, vol. 16, no. 2, 2004, pp. 301-328. 
KIRBY, Peadar, et al. Reinventing Ireland: Culture, Society and the Global Economy. Pluto, 2002.

LEWIS, Michael. Boomerang: Travels in the New Third World. Norton, 2011.

MCCANN, Colum. "Irish Identity is Work of Art Not Political Expediency." The Irish Times, March 16, 2013.

---. TransAtlantic. Bloomsbury, 2013.

MARANGOS, John. "The Evolution of the Term 'Washington Consensus'." Journal of Economic Surveys, vol. 23, no. 2, 2009, pp. 350-384.

MAHLER, Jonathan and Jim Rutenberg. "How Rupert Murdoch's Empire of Influence Remade the World." The New York Times Magazine, April 3, 2019.

MUNCK, Ronaldo. "Ireland in the World, the World in Ireland." Globalization, Migration and Social Transformation, edited by Bryan Fanning and Ronaldo Munck, Routledge, 2016, pp. 3-20.

MURPHY, Angela F. American Slavery, Irish Freedom: Abolition, Immigrant Citizenship, and the Transatlantic Movement for Irish Repeal. Louisiana State UP, 2010.

NAIM, Moises. "Fads and Fashion in Economic Reforms: Washington Consensus or Washington Confusion?" Third World Quarterly, vol. 21 , no. 3, 2000, pp. 505-528.

Narrative 4. https:/ / narrative4.com/. Accessed June 25, 2020.

OBAMA, Barack. "Remarks by the President at Irish Celebration in Dublin, Ireland." White House. May 23, 2011. https: / /obamawhitehouse.archives.gov/the-pressoffice/2011/05/23/remarks-president-irish-celebration-dublinireland. Accessed June 25, 2020.

O'HEARN, Denis. "Globalization, 'New Tigers,' and the End of the Developmental State? The Case of the Celtic Tiger." Politics \& Society vol. 28, no. 1, 2000, pp. 67-92.

Ó RIAIN, Seán. “The Flexible Developmental State: Globalization, Information Technology and the 'Celtic Tiger'." Politics and Society, vol. 28, no. 2, 2000, pp. 157-193. 
---. The Rise and Fall of Ireland's Celtic Tiger: Liberalism, Boom and Bust. Cambridge UP, 2014.

O'TOOLE, Fintan. Ship of Fools: How Stupidity and Corruption Sank the Celtic Tiger. Faber \& Faber, 2009.

RIACH, Douglas C. "Ireland and the Campaign against American Slavery 1830-1860." Diss. U of Edinburgh, 1975.

RODGERS, Nini. Ireland, Slavery and Anti-Slavery: 1612-1865. Springer, 2007.

SAID, Edward W. Humanism and Democratic Criticism. Columbia UP, 2004.

SIDDIQUI, Sabrina. "Fox News: How an Anti-Obama Fringe Set the Stage for Trump." The Guardian, March 19, 2019.

STIGLITZ, Joseph and Lindsey Schoenfelder. "Challenging the Washington Consensus." The Brown Journal of World Affairs, vol. 9, no. 2, 2003, pp. 33-40.

SWEENEY, Fionnghuala. Frederick Douglass and the Atlantic World. Liverpool UP, 2007.

TUCKER, Amanda. “'Our Story is Everywhere': Colum McCann and Irish Multiculturalism." Irish University Review, vol. 40, no. 2, 2010, pp. 107-128.

"What it Means to be Irish." The Gathering, www.thegatheringireland.com/beingirish.aspx. Accessed October 10 2013.

WHELAN, Kevin. "The Green Atlantic: Radical Reciprocities between Ireland and America in the Long Eighteenth Century." A New Imperial History: Culture, Identity, and Modernity in Britain and the Empire, 1660-1840, edited by Kathleen Wilson, Cambridge UP, 2004, pp. 216-238.

WILLIAMSON, John. "A Short History of the Washington Consensus." Law \& Bus. Rev. Am., vol. 15, no. 1, 2009, pp. 7-23.

---. "What Washington Means by Policy Reform." Latin American Readjustment: How Much has Happened, edited by John Williamson, Peterson, 1990, pp. 90-120. 